\title{
The ice flux to the Lambert Glacier and Amery Ice Shelf along the Chinese inland traverse and implications for mass balance of the drainage basins, East Antarctica
}

\author{
Xiangbin Cui ${ }^{1}$, Wenjia Du², Huan Xie ${ }^{2}$ \& Bo Sun ${ }^{1}$ \\ 'Polar Research Institute of China, Shanghai, China \\ ${ }^{2}$ Center for Spatial Information Science and Sustainable Development and College of Surveying and Geo-Informatics, Tongji University, Shanghai, China
}

\begin{abstract}
Study of the mass balance of the Antarctic Ice Sheet is critical to estimate its potential contribution to global sea-level rise in the future. As the largest drainage system, the Lambert Glacier-Amery Ice Shelf drainage system plays an important role in the mass balance of the Antarctic Ice Sheet. In this study, the ice thickness measured by airborne ice-penetrating radar with high spatial resolution and accuracy and accurate ice velocity measured by in situ GPS stations along the route of the Chinese National Antarctic Research Expedition inland traverse were used to calculate the ice flux with unprecedented accuracy. This transverse is from Zhongshan Station to Dome A, passing through the east side of the Lambert Glacier and the smaller coastal glacier in the C-Cp basin. The results show that the ice flux across the entire traverse is $24.7 \pm 2.8 \mathrm{Gt} \mathrm{a}^{-1}$, along which the section in drainage basin $\mathrm{B}-\mathrm{C}$ (Lambert Glacier) has an ice flux of $20.9 \pm 1.9 \mathrm{Gt} \mathrm{a}^{-1}$ and the section in drainage basin $\mathrm{C}-\mathrm{Cp}$ (basin adjacent to Lambert Glacier) contributed $3.8 \pm 0.4 \mathrm{Gt} \mathrm{a}^{-1}$. The ice flux values in both regions are coincident with the mass balance calculated from the Ice, Cloud, and Land Elevation Satellite, Earth Observing System. Meanwhile, the $\mathrm{C}-\mathrm{Cp}$ basin shows an ice flux value of $6.6 \pm 0.8 \mathrm{Gt} \mathrm{a}^{-1}$ across the grounding line.
\end{abstract}

\section{Keywords}

Surface mass balance; ice-penetrating radar; ice thickness; drainage system; Dome A; Antarctic Ice Sheet

\section{Correspondence}

Huan Xie, Center for Spatial Information Science and Sustainable Development and College of Surveying and Geo-Informatics, Tongji University, Shanghai, 200092, China. E-mail: huanxie@tongji.edu.cn

\author{
Abbreviations: \\ AIS: Antarctic Ice Sheet \\ ANARE: Australian National Antarctic \\ Research Expedition \\ CHINARE: Chinese National Antarctic \\ Research Expedition \\ CHINARE DT: Chinese inland traverse from \\ Zhongshan Station to Dome A \\ DEM: digital elevation model \\ EAIS: East Antarctic Ice Sheet \\ ICESat: Ice, Cloud, and Land Elevation \\ Satellite, Earth Observing System \\ IMBIE: Ice Sheet Mass Balance Inter- \\ comparison Exercise (international \\ collaboration to improve estimates of Antarctic \\ and Greenland ice-sheet contributions) \\ InSAR: interferometric synthetic aperture \\ radar \\ LAS: Lambert-Amery system \\ LGB: Lambert Glacier Basin \\ MOA: Mosaic of Antarctica on board the \\ Terra satellite \\ MODIS: moderate resolution imaging \\ spectroradiometer \\ SAR: synthetic aperture radar \\ SMB: surface mass balance
}

\section{Introduction}

The AIS holds approximately 26.5 million $\mathrm{km}^{3}$ of ice, having a potential contribution to global sea-level rise of approximately $58.3 \mathrm{~m}$ (Stocker et al. 2013). Even a small change of mass balance of the AIS might have a substantial influence on future sea-level change. Satellite measurements have shown that ice mass is being discharged into the Southern Ocean through the different drainage systems at an accelerating pace in Antarctica (Rignot, Velicogna et al. 2011; Pritchard et al. 2012; Kingslake et al. 2017). The marine-based West AIS is experiencing obvious mass loss, driven by increasing ocean and surface temperatures (Harig \& Simons 2015; Wouters et al. 2015). Recently, the mass balance and stability of the EAIS has drawn lots of attention on the account of its significant potential contribution to global sea level (Silvano et al. 2016; Golledge et al. 2017; Nitsche et al. 2017). 
EAIS contains four times the ice mass volume of the West AIS. Recently and in the past, EAIS has also shown instability in the drainage systems of Aurora Subglacial Basin and Wilkes Subglacial Basin in Wilkes Land (Young et al. 2011; Greenbaum et al. 2015; Aitken et al. 2016; Shen et al. 2018; Rignot et al. 2019).

The Amery Ice Shelf, the Lambert Glacier and the upstream areas constitute the largest drainage system in the area (LAS hereafter), located at 68.5-81 ${ }^{\circ} \mathrm{S}$ (near the ice divide in the central EAIS), $40-95^{\circ} \mathrm{E}$ in Antarctica (Fricker, Hyland et al. 2000). The ice in the drainage system drains into the narrow front of the Amery Ice Shelf, which accounts for only $2.5 \%$ of the coastline of the EAIS, with a very strong flow convergence and acceleration as the ice approaches the coast (Fricker, Hyland et al. 2000). The LAS has an area of 1.6 million $\mathrm{km}^{2}$, which accounts for $16 \%$ of the grounded area of the EAIS, and therefore plays an important role in the overall mass balance of the EAIS under a range of future warming climate and extreme scenarios. Regional modelling results with relatively high spatial resolution indicate the drainage system will be rather stable over the next several hundred years (Gong et al. 2014; Pittard et al. 2017), but mass balance of the LAS still has much uncertainty in terms of SMB and subglacial conditions (Pattyn \& Morlighem 2020). A number of pinning points beneath the Amery Ice Shelf and massifs around grounding lines, for example, Clemence Massif and Budd Ice Rumples, stabilize the LAS by providing strong lateral resistance. However, if the calving front of the ice shelf is moved to the south of the massif or if sufficient thinning happens south of the massif, grounding lines will retreat and upstream glaciers will accelerate significantly, increasing dynamic changes of the LAS (Gong et al. 2014; Pittard et al. 2017).

As for the aspect of sub-drainage basins, the mass input (mainly as the ice stream supply and precipitation) and output (mainly as the ice-shelf calving and basal melting) of the LAS have been studied over several decades (Budd 1966; Higham et al. 1997; Yu et al. 2010; Xie et al. 2016). Early studies of the mass budget and ice velocity of the LAS were mainly undertaken by the ANARE. During 1989-1995, five seasons of data were collected along the ANARE LGB traverse over the LAS along the ice surface contour line of approximately 2500 $\mathrm{m}$. The surface ice velocity was measured at $30-\mathrm{km}$ intervals along most of the traverse and at $15-\mathrm{km}$ intervals across the major stream, by repeating static GPS observations. Along the traverse, ice surface stakes used for snow accumulation measurement were set every $2 \mathrm{~km}$. The ice thickness along the traverse was surveyed by a $100-\mathrm{MHz}$ ice-penetrating radar system. Based on these systematic in situ measurements, Fricker, Warner et al. (2000) calculated an ice flux of $44 \mathrm{Gt}^{-1}$ across the LGB traverse. Extensive airborne geophysical measurements of ice thickness in the LAS were made by ANARE during 1972/73 and 1973/74, the Soviet Antarctic Expedition during 1987/88 (SAE33) and 1989/90 (SAE35), the Russian Antarctic Expedition during 1994/95 (RAE39; Lythe \& Vaughan 2001) and the Prince Charles Mountains Expedition of Germany and Australia during 2002/03 (Damm 2007). During the fourth International Polar Year (2007-09), a seven-nation international airborne geophysical project in Antarctica's Gamburtsev Province surveyed the southern part of the LAS (Ferraccioli et al. 2011). These projects have provided our main knowledge of the ice thickness and subglacial topography of the LAS. Using ice thickness measurements across grounding lines as input, Yu et al. (2010) estimated ice flux discharged into the Amery Ice Shelf to be $64.3 \pm 3.2$ $\mathrm{Gt} \mathrm{a}^{-1}$, while Wen et al. (2014) gave an ice flux of $36.3 \pm$ $2.7 \mathrm{Gt} \mathrm{a}^{-1}$ through the Amery Ice Shelf southern grounding line. However, most of these measurements paid attention to the downstream of the LAS, and they did not provide a long and continuous transect that could be used to calculate an accurate ice mass loss so as to estimate the mass balance of the region. Other studies of the mass balance of the LAS have mainly been based on satellite and modelling results (Thompson \& Pollard 1997; Smith et al. 1998; Fricker, Warner et al. 2000; Rignot \& Thomas 2002; van de Berg et al. 2005; Wen et al. 2008; Xie et al. 2016), but the conclusions of these studies did not consistently agree because the scale of observations varied and there is a lack of LAS-wide regional or local agreement.

During the 32nd CHINARE (CHINARE 32), in 2015/16, airborne ice-penetrating radar was used to survey the CHINARE DT (Fig. 1). The traverse, which comprised ice-flow monitoring stations at $30-\mathrm{km}$ intervals, bamboo stakes (to measure snow accumulation) at $2-\mathrm{km}$ intervals and several automatic weather stations, had been established during CHINARE 21, when a Chinese inland traverse team first visited Dome A in 2004/05. The whole traverse has since been studied in detail, including surface snow accumulation and ice-flow velocity (Zhang et al. 2008; Ding et al. 2011). The traverse has a total length of about $1250 \mathrm{~km}$ and passes through 2 of the 18 drainage basins in Antarctica as defined by Rignot, Mouginot et al. (2011), which are known as basins $\mathrm{B}-\mathrm{C}$ and $\mathrm{C}-\mathrm{Cp}$. In this paper, we describe how we calculated the ice flux across the traverse using the airborne observations of ice thickness and in situ measurements of ice-flow velocity and surface snow accumulation, and we discuss the mass balance of the LAS by comparing our results with several earlier studies. 


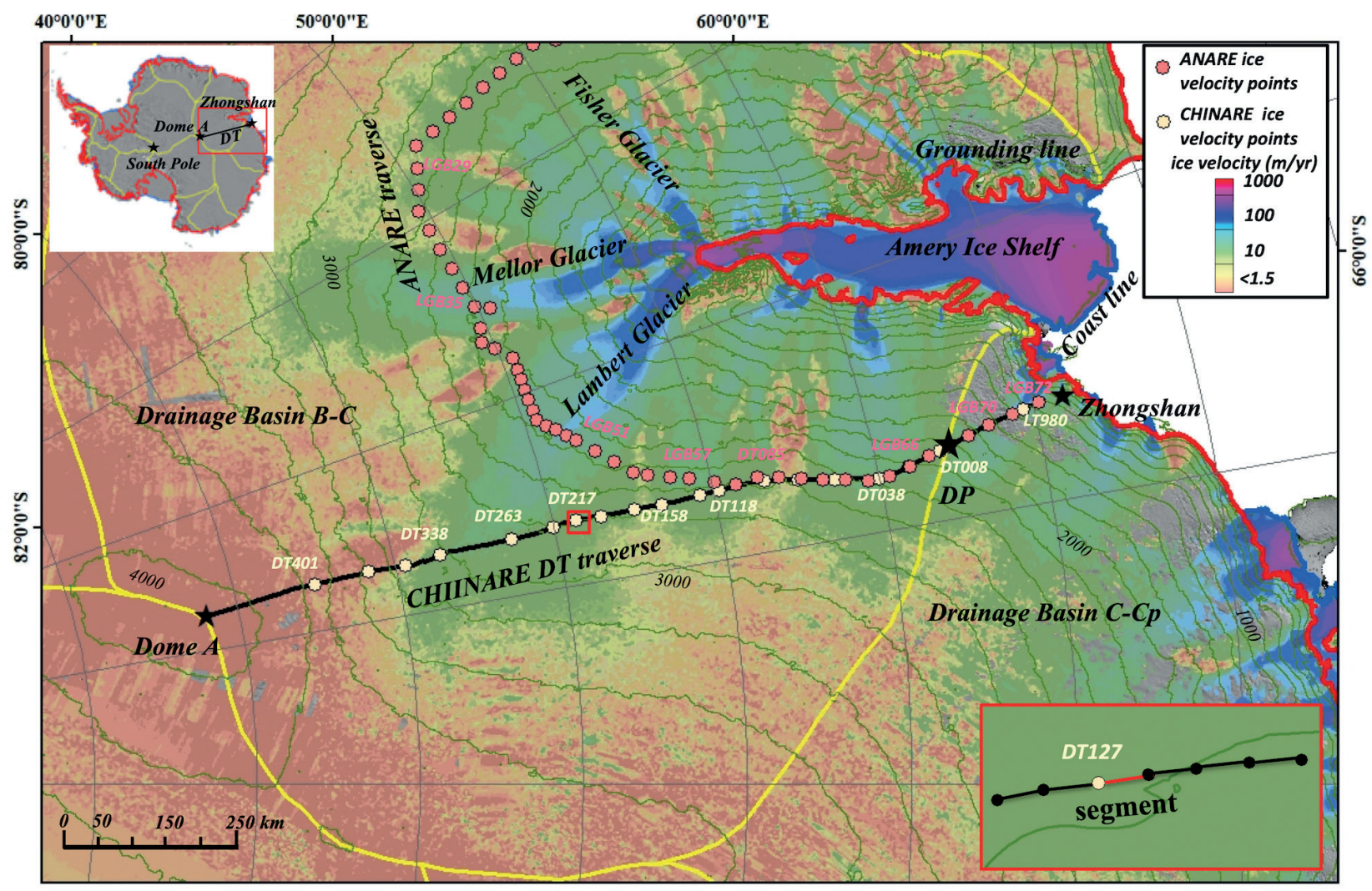

Fig. 1 The traverse between Zhongshan Station and Dome A, on the eastern side of the LAS, shown as the CHINARE DT traverse and marked with the thick black line. The pink and pale yellow dots are the GPS ice-flow monitoring points along the ANARE LGB and CHINARE DT traverses, respectively. The yellow lines demarcate the drainage basins defined by Rignot, Mouginot et al. (2011) and used by IMBIE Team (2018). The surface elevation contours - shown as thin green lines at 200-m intervals-are from Bamber et al. (2009). The thick red and blue lines are the grounding line and coastline, respectively, from the 2007-09 International Polar Year Program (Rignot et al. 2013; Mouginot et al. 2017). The background is the ice velocity from Rignot, Mouginot et al. (2011) over the MODIS MOA image (Scambos et al. 2007; Haran et al. 2014). We defined the crossover point of the CHINARE DT traverse and drainage basin line as the divisional point (DP). The total traverse is divided into the upper part (Dome A-DP) and the lower part (DP-Zhongshan Station). Drainage basin B-C contains three main glaciers: Lambert Glacier, Fisher Glacier and Mellor Glacier.

\section{Materials and methods}

\section{Data acquisition and integration}

Ice thickness. During the CHINARE 32, the ice thickness along the CHINARE DT traverse was measured by airborne ice-penetrating radar. The updated High-Capability Airborne Radar Sounder configured on the Snow Eagle 601, a BT-67 aircraft deployed by China for Antarctic expeditions, was used for the measurements (Cui et al. 2018). The raw radar data were separated into high- and low-gain channel data, and then pulse compression, filtering, coherent integration and incoherent integration were applied, resulting in a radar data set that is sampled every $10 \mathrm{~m}$ along-track. In addition, pulse compression in the $15-\mathrm{MHz}$ bandwidth enables a depth resolution of approximately $10 \mathrm{~m}$ in air and $5.6 \mathrm{~m}$ in ice. The processed radar data were plotted into radar grams along the traverse, with the horizontal coordinates of the traces and the measuring time and vertical coordinates of the radar signal range and sampling time. The electromagnetic signal propagation speed in ice was assumed to be a constant of $1.69 \times 10^{8} \mathrm{~m} / \mathrm{s}$ when transforming the sampling time to penetration depth. When the ice-bedrock interface was detected by the radar system, the snow surface and icebedrock interface were automatically traced and digitized while constraining the upper and lower boundaries manually, using the software developed by the University of Texas Institute for Geophysics. The airborne JAVAD GPS receiver provides accurate positioning and altitude data for the aircraft, with a data sampling frequency of $2 \mathrm{~Hz}$. 
Finally, the ice thickness was considered as being equal to the difference between the ice-bedrock interface and the snow surface. The ice-thickness data along the traverse start at the point of $76.44^{\circ} \mathrm{E}, 69.63^{\circ} \mathrm{S}$, near Zhongshan Station, and end at $76.92^{\circ} \mathrm{E}, 80.46^{\circ} \mathrm{S}$ at Dome A. Although most of the ice-bedrock interface along the traverse was detected by the airborne radar system, the ice-bedrock interface across the Lambert Glacier was not fully detected because of the complex ice structure and very thick ice. In this study, the missing ice-thickness data from 300 to $500 \mathrm{~km}$ along the traverse were filled with Bedmap2 ice-thickness data (Fretwell et al. 2013). The ice-thickness data of Bedmap2 were obtained by the Antarctica's Gamburtsev Province project, which has dense airborne ice-penetrating radar lines in the region, providing a relatively accurate ice thickness in the small data gap. The ice thicknesses from Bedmap2 and CHINARE are in agreement along the whole of the traverse (Fig. 2a), except for an obvious underestimation of the ice thickness at 900-950 km. However, the ice thickness from Bedmap2 is seriously smoothed when interpolated. Compared with Bedmap2, the ice thickness from CHINARE shows a higher level of detailed local changes along the traverse.

Ice velocity. The ice-velocity data used in this study were the in situ surface velocity measurements collected along the CHINARE DT (1997-2005) traverse (Zhang et al. 2008). Because of the sparseness of these in situ observation data, we used the CHINARE bamboo stake positions (used to monitor surface snow accumulation) as interpolation points (with approximately $2 \mathrm{~km}$ between adjacent stakes) to obtain the ice velocity (2007-09) from the satellite ice flow map (Rignot, Mouginot et al. 2011). The ice-velocity data were transformed into the same projection/coordinate system (EPSG: 3031 WGS 84/Antarctic Polar Stereographic).

The ANARE LGB (1989-1995) ice-velocity data were also used for comparison (Manson et al. 2000). The routes of the ANARE LGB and CHINARE DT traverses are similar in the beginning and then separate after the DT085 point (Fig. 1). For the ice velocities from the SAR and InSAR velocity map (Rignot, Mouginot et al. 2011), CHINARE and ANARE show a good agreement along the traverse (Fig. 2b). For the initial part of the DT traverse, about $0-270 \mathrm{~km}$, both the in situ measurements and remote sensing results show a very slow ice flow of close to $0 \mathrm{~m} \mathrm{a}^{-1}$. In the coastal area around $1000 \mathrm{~km}$, there are several points that show a difference between the remote sensing observations and the in situ measurements. In this situation, the in situ measurements were used with priority.

Bedrock and surface slope data. The bedrock slope data were extracted from the Bedmap2 bedrock DEM with a resolution of $1 \mathrm{~km}$ (Fretwell et al. 2013). Bedmap2 is an improved version of Bedmapl, containing surface elevation, the seafloor, subglacial bed elevation and ice thickness, with a resolution of $1 \mathrm{~km}$. The surface slope data were calculated from the ICESat DEM (DiMarzio 2007). The ICESat DEM was provided at the National Snow and Ice Data Center, with a resolution of $500 \mathrm{~m}$ in the area north of $86^{\circ} \mathrm{S}$. In order to avoid being affected by the micro-topography, the surface and bedrock DEMs were down-sampled to $30-\mathrm{km}$ resolution. The slope of the position was calculated using a quadratic surface to fit the micro-topography in $3 \times 3$ cells over the DEM.

RACMO 2.3. This is a semi-empirical regional atmospheric climate model that can simulate regional atmospheric climate at a relatively high horizontal resolution (van Wessem et al. 2014; van Wessem et al. 2018). In particular, the simulated SMB of the glaciated regions has been widely used in the mass-balance evaluation of the AIS. In this study, we used the monthly SMB data of RACMO2.3 (with a resolution of $27.5 \mathrm{~km}$ ) to calculate the input mass of the upstream area of the DT traverse in the drainage basin $\mathrm{B}-\mathrm{C}$ and the downstream area of the DT traverse in the drainage basin $\mathrm{C}-\mathrm{Cp}$.

\section{Ice-flux calculation}

Combining the in situ ice-velocity data and the interpolation velocity from Rignot's ice-velocity map, the CHINARE DT traverse was divided into 608 segments. Each pair of adjacent points formed a segment (Fig. 1), and for each segment we took the component of the depthaveraged velocity, which is perpendicular to the segment direction. The ice flux of the traverse can be calculated as

$$
Q=\sum_{i=1}^{N} \rho H_{i} l_{i} u_{i}
$$

where $N$ is the number of segments, $H_{i}$ is the ice thickness of the $i$ th segment, $l_{i}$ is the width of the $i$ th segment and $u_{i}$ is the depth-averaged velocity of the $\mathrm{i}^{\text {th }}$ segment perpendicular to the flux gate. The details of how to calculate the depth-averaged velocity from the surface velocity are presented in the Supplementary material. Here, $\rho$ denotes the average density of the ice column as the density changes from the firn layer to the frozen ice, which can be represented by an empirical density-depth relation (Cuffey \& Paterson 2010):

$$
\rho=\left(\int_{0}^{H} \rho_{i}-\left(\rho_{i}-\rho_{s}\right) \exp \left(-z / z_{\rho}\right)\right) / H,
$$

where $H$ is the ice thickness, $\rho_{i}$ is the density of ice $(917$ $\mathrm{kg} \mathrm{m}^{-3}$ ) and $\rho$ is the density of surface snow (in situ measurements along the CHINARE traverse). Parameter $\mathrm{z}$ 

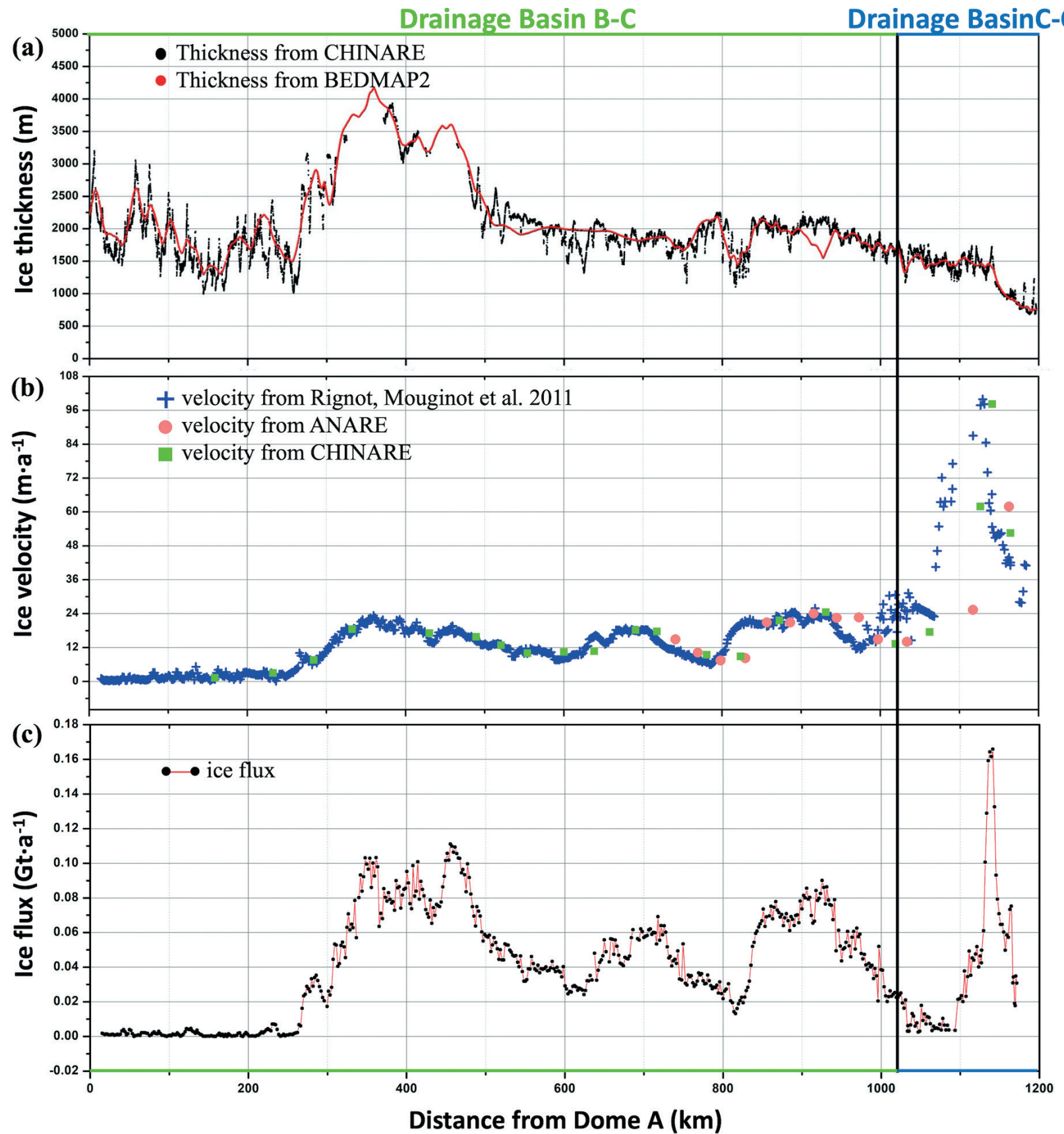

Fig. 2 (a) Ice-thickness data comparison between the CHINARE airborne ice-penetrating radar measurements (2015/16) and Bedmap2 (2013). (b) Ice-velocity data comparison between ANARE (1989-1995), CHINARE (1996-2005) and satellite observations (2007-09; Rignot, Mouginot et al. 2011). (c) Ice-flux values along the CHINARE DT traverse of 608 segments. The different drainage basins and their boundaries are shown at the top and the bottom of the figure.

represents a certain depth, and $z_{\rho}$ is a constant for each site, corresponding to a characteristic depth of the firn.

We calculated the ice flux of each segment along the traverse (Fig. 2c) based on the data interpolation of the ice thickness and ice velocity, and we summed them using Eqn. 1 as the total ice flux.

\section{Surface mass balance}

We estimated the surface snowfall of the sub-drainage basins using the SMB data of RACMO2.3 (van Wessem et al. 2014). The yearly SMB was averaged from the corresponding monthly data. These yearly data were 
averaged to the study time period and were resampled to a $10-\mathrm{km}$ cell-size grid using the kriging interpolation method. The total SMB of the upper region of the traverse in basin $\mathrm{B}-\mathrm{C}$ (Lamber Glacier) and the upper region of the traverse in basin C-Cp (basin adjacent to Lambert Glacier) is equal to their area multiplied by the annual SMB over the area.

\section{Uncertainty estimation}

Sources of error in ice-flux estimation include uncertainties in the ice velocity and ice thickness. The ice-velocity error was extracted from Rignot's ice-velocity error map (Rignot, Mouginot 2011) and ranged 0-17 $\mathrm{m} \mathrm{a}^{-1}$. Ice-thickness error mainly comes from the assumption of electromagnetic wave propagation velocity in ice and manual ice-bedrock interface digitization but can be controlled in a range of 30-100 m (Cui et al. 2010; Fretwell et al. 2013). The uncertainty of the yearly SMB result was estimated by calculating the time series of the annual totals and taking the standard deviation. We quantified the error of the ice flux and mass balance based on the statistical theory of error propagation (Taylor 1997).

\section{Results}

According to the data and methods described earlier, the total ice flux across the CHINARE traverse is $24.7 \pm$ $2.8 \mathrm{Gt} \mathrm{a}^{-1}$. Figure 3 shows that the traverse is divided into two parts: the upper part from Dome A to divisional point (DP) in drainage basin B-C (Lambert Glacier) and the lower part from DP to Zhongshan in drainage basin C-Cp (basin adjacent to Lambert Glacier). The ice flux values for the two parts are $20.9 \pm 1.9$ and $3.8 \pm 0.4 \mathrm{Gt}$ $\mathrm{a}^{-1}$, respectively. The upper region of the drainage basin B-C contributes most of its ice to the southern boundary of the Amery Ice Shelf through the Lambert Glacier. Our results show that $85 \%$ of the ice flux across the traverse is flowing into the shelf of the LAS, contributed by drainage basin B-C. Moreover, the ice flux is significantly different on the south and north sides of the $78^{\circ} \mathrm{S}$ line (close to the $3200 \mathrm{~m}$ contour line of the surface). Almost all of the

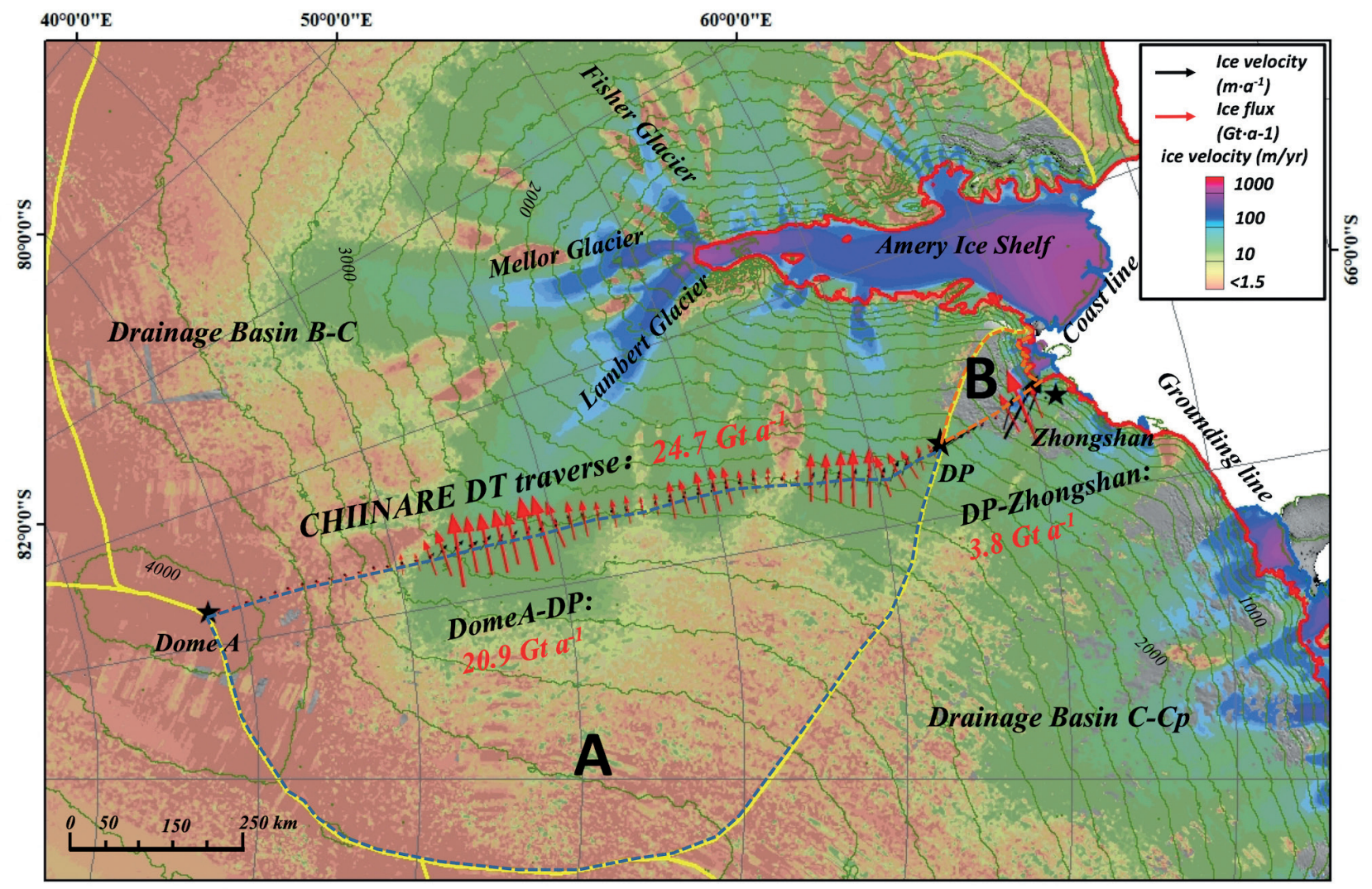

Fig. 3 Ice flux across the CHINARE DT traverse between Zhongshan Station and Dome A. The ice-velocity and ice-flux values are represented by the black and red arrows, respectively, at an interval of $20 \mathrm{~km}$. The total ice flux of the CHINARE DT traverse is $24.7 \pm 2.8 \mathrm{Gt} \mathrm{a}^{-1}$, the ice flux of the upper part (Dome $\mathrm{A}-\mathrm{DP}$ ) is $20.9 \pm 1.9 \mathrm{Gt} \mathrm{a}^{-1}$, and the ice flux of the lower part (DP-Zhongshan) is $3.8 \pm 0.4 \mathrm{Gt} \mathrm{a}^{-1}$. 
ice flux comes from the north part, on the account of the relatively fast ice flow and thick ice in the Lambert Glacier. In the southern part, the ice flux is close to zero as a result of the very slow ice flow in the Dome A area. Most of the ice across the lower part of the traverse in drainage basin $\mathrm{C}-\mathrm{Cp}$ flows out to the ocean through the coastal glaciers, and the ice flux of $3.8 \pm 0.4 \mathrm{Gt} \mathrm{a}^{-1}$ accounts for $15 \%$ of the total flux.

In terms of the component method, we calculated the snowfall using RACMO2.3 over the two enclosed interior regions (A and $\mathrm{B}$ ) defined between the DT traverse and the drainage basins $\mathrm{B}-\mathrm{C}$ and $\mathrm{C}-\mathrm{Cp}$, which are $21.0 \pm 0.2$ and $2.2 \pm 0.1 \mathrm{Gt} \mathrm{a}^{-1}$, respectively. We also calculated the discharge from the lower region (B) across the grounding line to the ocean as $6.6 \pm 0.8 \mathrm{Gt} \mathrm{a}^{-1}$. The mass-balance results of the two regions using the input-output method are shown in Table 1 and compared with the recalculated results from an overall LAS mass change using ICESat data (Xie et al. 2016). For the upper region of the traverse in drainage basin $\mathrm{B}-\mathrm{C}$, the ICESat result is $0.5 \pm 0.2 \mathrm{Gt} \mathrm{a}^{-1}$, while the input-output method gives $0.1 \pm 1.9 \mathrm{Gt} \mathrm{a}^{-1}$. For the lower region of the traverse in drainage basin $\mathrm{C}-\mathrm{Cp}$, the input is made up of the input ice flux from upstream and the snowfall in this region. The output is the discharge across the grounding line, and the mass balance from the input-output method shows a result of $-0.6 \pm 0.9 \mathrm{Gt} \mathrm{a}^{-1}$. In contrast, ICESat shows $-0.3 \pm 0.1 \mathrm{Gt} \mathrm{a}^{-1}$. Despite the difference in time period, the mass balances of the two regions match the ICESat results, within their uncertainties. We compared the RACMO2.3 SMB data with the in situ SMB observations from the CHINARE stakes to verify the regional atmospheric climate model (Fig. 4). Along the CHINARE traverse, the snowfall of the interior region was obviously less than that in the region near the coastline. Although the overestimation of SMB by RACMO2.3 can be noticed between about 600 and $1000 \mathrm{~km}$, the correlation coefficient of the two data sources is up to 0.76 along the traverse. Moreover, a detailed comparison of Antarctic SMB between reanalysis and regional atmospheric climate model products and in situ observations shows RACMO2.3 has the best correlation (Wang et al. 2016). These indicate that the RACMO 2.3 data are a relatively reliable way to represent the SMB over this region.

\section{Discussion}

To date, many studies have estimated the ice flux of the LAS across the grounding line (Wen et al. 2007; Yu et al. 2010; Wen et al. 2014). However, the ice-movement measurements and ice-flux calculations have indicated

Table 1 Mass balance of the LAS from the east side, East Antarctica (1997-2009).

\begin{tabular}{|c|c|c|c|c|c|}
\hline & \multicolumn{5}{|c|}{ Input/output mass balance (Gt $\left.\mathrm{a}^{-1}\right)$} \\
\hline & $\begin{array}{l}\text { Input: SMB from } \\
\text { RACMO2.3 }\end{array}$ & Input: ice flux & Output: ice flux & $\begin{array}{l}\text { Mass balance in this } \\
\text { paper (1992-2009) }\end{array}$ & $\begin{array}{l}\text { Mass balance derived } \\
\text { from ICESat }^{a}(2003-08)\end{array}$ \\
\hline $\begin{array}{l}\text { Upper region of the drainage } \\
\text { basin B-C (Lambert Glacier) }\end{array}$ & $21.0 \pm 0.2$ & - & $20.9 \pm 1.9$ & $0.1 \pm 1.9$ & $0.5 \pm 0.2$ \\
\hline $\begin{array}{l}\text { Lower region of the drainage } \\
\text { basin } C-C p\end{array}$ & $2.2 \pm 0.1$ & $3.8 \pm 0.4$ & $6.6 \pm 0.8$ & $-0.6 \pm 0.9$ & $-0.3 \pm 0.1$ \\
\hline
\end{tabular}

a Mass-balance re-estimation from ICESat for 2003-08 (Xie et al. 2016).

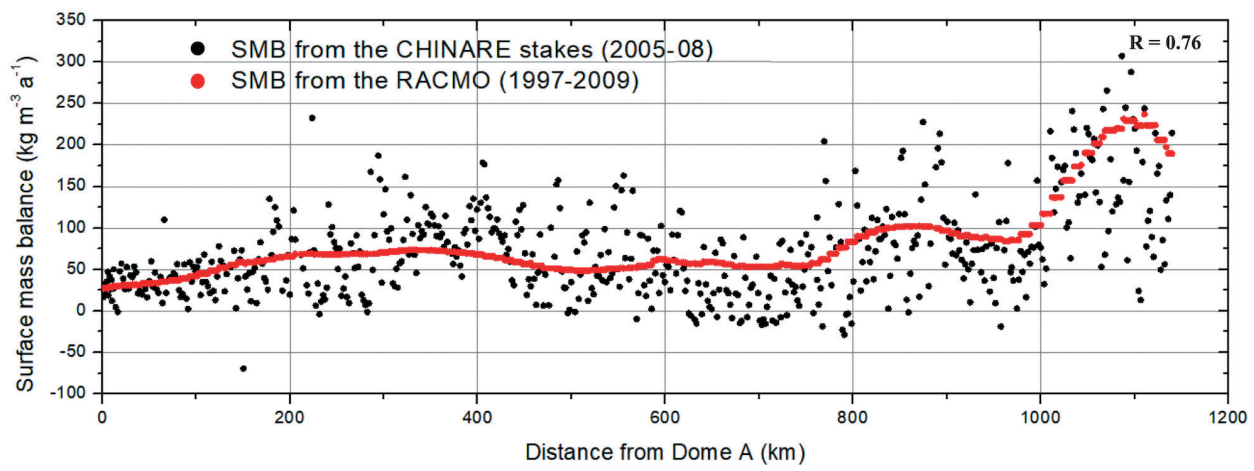

Fig. 4 In situ SMB observation from the CHINARE stakes for 2005-08 (black dots) and the SMB values extracted from RACMO2.3 for the stakes' locations over the study period (red dots). 
that the ice velocity and ice flux on the east side are higher than those on the west side of the LAS, meaning that the major part of the mass supply for the LAS is from the east (Ren et al. 2002). As the locations of the ANARE LGB and CHINARE DT traverses are similar and sometimes overlapping, we compared the ice flux through the east side of the LGB traverse with our results.

Fricker, Warner et al. (2000) calculated the ice flux across the LGB traverse and reported the ice flux over the west (LGB00-32, about $1000 \mathrm{~km}$ ), east (LGB56-72, about $500 \mathrm{~km}$ ) and stream (LGB32-56, about $500 \mathrm{~km}$ ) segments to be $13.6,8.6$ and $21.8 \mathrm{Gt} \mathrm{a}^{-1}$, respectively. The east side of the LGB traverse has an overlap of $420 \mathrm{~km}$ with our traverse. As the east side of the LGB traverse contributes little to the Lambert Glacier, the ice flux results are lower than our result $\left(8.6 \mathrm{Gt} \mathrm{a}^{-1}\right.$ vs. $\left.24.7 \pm 2.8 \mathrm{Gt} \mathrm{a}^{-1}\right)$. Wen et al. (2006) also calculated the ice flux across the LGB traverse. The ice discharge was calculated for the Fisher Glacier, the Mellor Glacier and the Lambert Glacier and in drainage basins 9 and 11 (the Antarctica drainage basins studied by Zwally et al. [2012]). They found the sum of the ice flux from the Lambert Glacier and drainage basin 11 to be comparable with our result for $350 \mathrm{~km}$ of overlapping route $\left(26.2 \pm 1.0 \mathrm{Gt} \mathrm{a}^{-1}\right.$ vs. $\left.24.7 \pm 2.8 \mathrm{Gt} \mathrm{a}^{-1}\right)$. This affirms that most of the ice in the eastern part of the drainage basin B-C contributes to the Lambert Glacier.

We assessed an improved and a detailed mass balance pattern for the eastern side of the LAS. The overall ice flux of the CHINARE DT traverse is $24.7 \pm 2.8 \mathrm{Gt} \mathrm{a}^{-1}$. The two enclosed regions crossed by the traverse in the drainage basins B-C and C-Cp showed ice flux values of $20.9 \pm 1.9$ and $3.8 \pm 0.4 \mathrm{Gt} \mathrm{a}^{-1}$, respectively. The upper region of the traverse is in the East Antarctic accumulation area, with a slightly positive mass balance (consistent with the result of Xie et al. [2016]). As a result of the large area and thick ice, $85 \%$ of the ice flux across the traverse flows into the shelf of the LAS, contributed by the drainage basin B-C. We found that the region of the lower traverse in drainage basin $\mathrm{C}-$ $\mathrm{Cp}$ has an overall negative mass balance, and although the precipitation is higher than for the interior ice sheet, the ice discharge across the grounding line is $6.6 \pm 0.8 \mathrm{Gt} \mathrm{a}^{-1}$.

\section{Conclusion}

In this study, a new ice thickness measured by airborne ice-penetrating radar with high spatial resolution and accuracy and accurate ice velocity measured by in situ GPS stations during the CHINAREs were used to calculate the ice flux along the route of the CHINARE DT and subsequently to estimate the mass balance of the region. The results of the study helped us to further understand the regional dynamics of LAS, East Antarctica.

\section{Acknowledgements}

The authors would like to thank the Chinese National Antarctic Research Expeditions for the field data collection and the anonymous reviewers for their careful work and thoughtful suggestions that have helped to improve this paper.

\section{Funding}

This work was supported by the National Key Research and Development Program of China (grant no. 2017YFA0603100), the Chinese National Natural Science Foundation (grant nos. 41730102, 41571407, 41822106, 41776186 and 41941006), the Shanghai Science and Technology Innovation Action Plan Programme (grant no. 18511102100), the Shuguang Programme supported by the Shanghai Education Development Foundation and Shanghai Municipal Education Commission (grant no. 18SG22), and the Fundamental Research Funds for the Central Universities.

\section{Disclosure statement}

The authors report no conflict of interest.

\section{References}

Aitken A.R., Roberts J.L., van Ommen T.D., Young D.A., Golledge N.R., Greenbaum J.S., Blankenship D.D. \& Siegert M.J. 2016. Repeated large-scale retreat and advance of Totten Glacier indicated by inland bed erosion. Nature 533, 385-389, doi: 10.1038/nature 17447 .

Bamber J., Gomez-Dans J.L. \& Griggs J.A. 2009. A new 1 km digital elevation model of the Antarctic derived from combined satellite radar and laser data. Part 1: data and methods. The Cryosphere 3, 101-111, doi: 10.5194/tc-3-101-2009.

Budd W. 1966. The dynamics of the Amery Ice Shelf. Journal of Glaciology 6, 335-358, doi: 10.3189/S0022143000019456.

Cuffey K. \& Paterson W. 2010. The physics of glaciers. 4th edn. Burlington, MA: Butterworth-Heinemann.

Cui X., Greenbaum J.S., Beem L.H., Guo J., Gregory N.G., Lin L., Blankenship D. \& Sun B. 2018. The first fixed-wing aircraft for Chinese Antarctic expeditions: airframe, modifications, scientific instrumentation and applications. Journal of Environmental and Engineering Geophysics 23, Special Issue S1, 1-13, doi: 10.2113/JEEG23.1.1.

Cui X., Sun B., Tian G., Tang X., Zhang X., Jiang Y., Guo J. \& Li X. 2010. Ice radar investigation at Dome A, East Antarctica: ice thickness and subglacial topography. Chinese Science Bulletin 55, 425-431, doi: 10.1007/ sl 1434-009-0546-z.

Damm V. 2007. A subglacial topographic model of the southern drainage area of the Lambert Glacier/Amery Ice Shelf 
system. Results of an airborne ice thickness survey south of the Prince Charles Mountains. Terra Antarctica 14, 85-94.

DiMarzio J.P. 2007. GLAS/ICESat 500 m laser altimetry digital elevation model of Antarctica. Version 1. Boulder, CO: National Snow and Ice Data Center.

Ding M., Xiao C., Li Y., Ren J., Hou S., Jin B. \& Sun B. 2011. Spatial variability of surface mass balance along a traverse route from Zhongshan Station to Dome A, Antarctica. Journal of Glaciology 57, 658-666, doi: 10.3189/00221431 1797409820.

Ferraccioli F., Finn C.A., Jordan T.A., Bell R.E., Anderson L.M. \& Damaske D. 2011 . East Antarctic rifting triggers uplift of the Gamburtsev mountains. Nature 479, 388-392, doi: 10.1038/nature10566.

Fretwell L.O., Pritchard H.D., Vaughan D.G., Bamber J.L., Barrand N.E., Bell R., Bianchi C., Bingham R.G., Blankenship D.D., Casassa G., Catania G., Callens D., Conway H., Cook A.J., Corr H.F.J., Damaske D., Damm V., Ferraccioli F., Forsberg R., Fujita S., Gogineni P., Griggs J.A., Hindmarsh R.C.A., Holmlund P., Holt J.W., Jacobel R.W., Jenkins A., Jokat W., Jordan T., King E.C., Kohler J., Krabill W., Riger-Kusk M., Langley K.A., Leitchenkov G., Leuschen C., Luyendyk B.P., Matsuoka K., Nogi Y., Nost O.A., Popov S.V., Rignot E., Rippin D.M., Riviera A., Roberts J., Ross N., Siegert M.J., Smith A.M., Steinhage D., Studinger M., Sun B., Tinto B.K., Welch B.C., Young D.A., Cui X. \& Zirizzotti A. 2013. Bedmap2: improved ice bed, surface and thickness datasets for Antarctica. The Cryosphere 7, 375-393, doi: 10.5194/tc-7-375-2013.

Fricker H.A., Hyland G., Coleman R. \& Young N.W. 2000. Digital elevation models for the Lambert Glacier-Amery Ice Shelf system, East Antarctica, from ERS-1 satellite radar altimetry. Journal of Glaciology 46, 553-560, doi: 10.3 189/172756500781832639.

Fricker H.A., Warner R.C. \& Allison I. 2000. Mass balance of the Lambert Glacier-Amery Ice Shelf system, East Antarctica: a comparison of computed balance fluxes and measured fluxes. Journal of Glaciology 46, 561-570, doi: 10 $.3189 / 172756500781832765$.

Golledge N.R., Levy R.H., Mckay R.M. \& Naish T.R. 2017. East Antarctic Ice Sheet most vulnerable to Weddell Sea warming. Geophysical Research Letters 44, 2343-2351, doi: 10.1002/2016GL072422.

Gong Y., Cornford S.L. \& Payne A.J. 2014. Modelling the response of the Lambert Glacier-Amery Ice Shelf system, East Antarctica, to uncertain climate forcing over the 21 st and 22nd centuries. The Cryosphere 8, 1057-1068, doi: 10.5194/tc-8-1057-2014.

Greenbaum J.S., Blankenship D.D., Young D.A., Richter T.G., Roberts J.L., Aitken A.R.A., Legresy B., Schroeder D.M., Warner R.C. \& van Ommen T.D. 2015. Ocean access to a cavity beneath Totten Glacier in East Antarctica. Nature Geoscience 8, 294-298, doi: 10.1038/ngeo2388.

Haran T., Bohlander J., Scambos T., Painter T. \& Fahnestock M. 2014. MODIS Mosaic of Antarctica 2008-2009 (MOA2009) image map. Version 1. Boulder, CO: National Snow and Ice Data Center.

Harig C. \& Simons F.J. 2015. Accelerated West Antarctic ice mass loss continues to outpace East Antarctic gains. Earth and Planetary Science Letters 415, 134-141, doi: 10.1016/j. epsl.2015.01.029.

Higham M., Craven M., Ruddell A. \& Allison I. 1997. Snow-accumulation distribution in the interior of the Lambert Glacier basin, Antarctica. Annals of Glaciology 25, 412-417, doi: 10.3189/S0260305500014373.

IMBIE Team 2018. Mass balance of the Antarctic Ice Sheet from 1992 to 2017. Nature 558, 219-222, doi: 10.1038/ s41586-018-0179-y.

Kingslake J., Ely J.C., Das I. \& Bell R.E. 2017. Widespread movement of meltwater onto and across Antarctic ice shelves. Nature 544, 349-352, doi: 10.1038/nature22049.

Lythe M.B. \& Vaughan D.G. 2001. BEDMAP: a new ice thickness and subglacial topographic model of Antarctica. Journal of Geophysical Research-Solid Earth 106, 11335-11351, doi: 10.1029/2000JB900449.

Manson R., Coleman R., Morgan P.J. \& King M.A. 2000. Ice velocities of the Lambert Glacier from static GPS observations. Earth, Planet, and Space 52, 1031-1036, doi: 10.1186/ BF03352326.

Mouginot J., Scheuchl B. \& Rignot E. 2017. MEaSUREs Antarctic boundaries for IPY 2007-2009 from satellite radar. Version 2. Boulder, CO: National Snow and Ice Data Center.

Nitsche F.O., Porter D., Williams G., Cougnon E.A., Fraser A.D., Correia R. \& Guerrero R. 2017. Bathymetric control of warm ocean water access along the East Antarctic margin. Geophysical Research Letters 44, 8936-8944, doi: 10.1002/2017GL074433.

Pattyn F. \& Morlighem M. 2020. The uncertain future of the Antarctic Ice Sheet. Science 367, 1331-1335, doi: 10.1126/ science.aaz5487.

Pittard M.L., Galton-Fenzi B.K., Watson C.S. \& Roberts J.L. 2017. Future sea level change from Antarctica's Lambert-Amery glacial system. Geophysical Research Letters 44, 7347-7355, doi: 10.1002/2017GL073486.

Pritchard H.D., Ligtenberg S.R.M., Fricker H., van den Broeke M.R., Vaughan D.G. \& Padman L., 2012. Antarctic Ice Sheet loss driven by basal melting of ice shelves. Nature 484, 502-505, doi: 10.1038/nature 10968.

Ren J., Allison I., Xiao C. \& Qin D. 2002. Mass balance of the Lambert Glacier basin, East Antarctica. Science China Earth Sciences 45, 842-850.

Ren J., Qin D. \& Allison I. 1999. Variations of snow accumulation and temperature over past decades in the Lambert Glacier basin, East Antarctica. Annals of Glaciology 29, 29-32, doi: 10.3189/172756499781821058.

Rignot E., Mouginot J. \& Scheuchl B. 2011. Ice flow of the Antarctic Ice Sheet. Science 333, 1427-1430, doi: 10.1126/ science. 1208336.

Rignot E., Mouginot J., Scheuchl B., van den Broeke M.R., van Wessem M. \& Morlighem M. 2019. Four decades of Antarctic Ice Sheet mass balance from 1979-2017. Proceedings of the National Academy of Sciences of the United States of America 116, 1095-1103, doi: 10.1073/pnas.1812883116.

Rignot E. \& Thomas R.H. 2002. Mass balance of polar ice sheets. Science 297, 1502-1506, doi: 10.1126/science.1073888.

Rignot E., Velicogna I., van den Broeke M.R., Monaghan A. \& Lenaerts J. 2011. Acceleration of the contribution 
of the Greenland and Antarctic ice sheets to sea level rise. Geophysical Research Letters 38, L05503-L05508, doi: 10.1029/2011GL046583.

Scambos T., Haran T., Fahnestock M., Painter T. \& Bohlander J. 2007. MODIS-based Mosaic of Antarctica (MOA) data sets: continent-wide surface morphology and snow grain size. Remote Sensing of Environment 111, 242-257, doi: 10.1016/j.rse.2006.12.020.

Shen Q., Wang H., Shum C.K., Jiang L., Hsu H.T. \& Dong J. 2018. Recent high-resolution Antarctic ice velocity maps reveal increased mass loss in Wilkes Land, East Antarctica. Scientific Reports 8, article no. 4477, doi: 10.1038/ s41598-018-22765-0.

Silvano A., Rintoul S.R. \& Herraiz-Borreguero L. 2016. Ocean-ice shelf interaction in East Antarctica. Oceanography 29, 130-143, doi: 10.5670/oceanog.2016.105.

Smith I.N., Budd W.F. \& Reid P. 1998. Model estimates of Antarctic accumulation rates and their relationship to temperature changes. Annals of Glaciology 27, 246-250, doi: 10.3189/1998AoG27-1-246-250.

Stocker T.F., Qin D., Plattner G.K., Tignor M., Allen S.K., Boschung J., Nauels A., Xia Y., Bex B. \& Midgley B. (eds.) 2013. Climate change 2013. The physical science basis. Contribution of Working Group I to the fifth assessment report of the Intergovernmental Panel on Climate Change. Cambridge: Cambridge University Press.

Taylor J. 1997. Introduction to error analysis: the study of uncertainties in physical measurements. New York: University Science Books.

Thompson S.L. \& Pollard D. 1997. Greenland and Antarctic mass balances for present and doubled atmospheric $\mathrm{CO}_{2}$ from the GENESIS version-2 global climate model. Journal of Climate 10, 871-900, doi: 10.1175/1520-0442(1997) $010<0871$ :GAAMBF>2.0.CO;2.

van de Berg W.J., van den Broeke M.R, Reijmer C.H. \& van Meijgaard E. 2005. Characteristics of the Antarctic surface mass balance (1958-2002) using a regional atmospheric climate model. Annals of Glaciology 41, 97-104, doi: 10.318 9/172756405781813302.

van Wessem J.M., Reijmer C.H., Morlighem M., Mouginot J., Rignot E., Medley B., Joughin I., Wouters B., Depoorter M.A., Bamber J.L., Lenaerts J.T.M., van de Berg W.J., van den Broeke M.R. \& van Meijgarrd E. 2014. Improved representation of East Antarctic surface mass balance in a regional atmospheric climate model. Journal of Glaciology 60, 761-770, doi: 10.3189/2014JoG14J051.

van Wessem J.M., van de Berg W.J., Noël B.P.Y, van Meijgaard E., Amory C., Birnbaum G., Jakobs C.L., Krüger K., Lenaerts J.T.M., Lhermitte S., Ligtenberg S.R.M, Medley B., Reijmer C.H., van Tricht K., Trusel L.D., van Ulft L.H., Wouters B., Wuite J., van den Broeke M.R. 2018. Modelling the climate and surface mass balance of polar ice sheets using RACMO2. Part 2: Antarctica (1979-2016). The Cryosphere 12, 1479-1498, doi: 10.5194/tc-2017-202.

Wang Y., Ding M., van Wessem J., Schlosser E., Altnau S., van den Broeke M.R., Lenaerts J.T.M., Thomas E.R., Isaksson E., Wang J. \& Sun W. 2016. A comparison of Antarctic
Ice Sheet surface mass balance from atmospheric climate models and in situ observations. Journal of Climate 29, 5317-5337, doi: 10.1175/JCLI-D-15-0642.1.

Wen J., Jezek K.C., Csatho B., Herzfeld U.C., Farness K.L. \& Huybrechts P. 2007. Mass budgets of the Lambert, Mellor and Fisher glaciers and basal fluxes beneath their flowbands on Amery Ice Shelf. Science in China Series D-Earth Sciences 50, 1693-1706, doi: 10.1007/s1 1430-007-0120-y.

Wen J., Jezek K.C., Monaghan A.J., Sun B., Ren J. \& Huybrechts P. 2006. Accumulation variability and mass budgets of the Lambert Glacier-Amery Ice Shelf system, East Antarctica, at high elevations. Annals of Glaciology 43, 351-360, doi: 10.3189/172756406781812249.

Wen J., Huang L., Wang W., Jacka T.H., Damm V. \& Liu Y. 2014. Ice thickness over the southern limit of the Amery Ice Shelf, East Antarctica, and reassessment of the mass balance of the central portion of the Lambert GlacierAmery Ice Shelf system. Annals of Glaciology 55, 81-86, doi: 10.3189/2014AoG66A154.

Wen J., Wang Y., Liu J., Jezek K.C., Huybrechts P., Csathó B.M., Farness K.L. \& Sun B. 2008. Mass budget of the grounded ice in the Lambert Glacier-Amery Ice Shelf system. Annals of Glaciology 48, 193-197, doi: 10.3189/172756408784700644.

Wouters B., Martinespañol A., Helm V., Flament T., van Wessem J.M., Ligtenberg S.R.M., van den Broeke M.R. \& Bamber J.L. 2015. Dynamic thinning of glaciers on the southern Antarctic Peninsula. Science 348, 899-903, doi: 10.1126/science.aaa5727.

Xie H., Li R., Tong X., Ju X., Liu J., Tian Y., Shen Y., Liu S., Sun B., Cui X., Ye W. \& Chen L. 2016. A comparative study of changes in the Lambert GlacierAmery Ice Shelf System, East Antarctica, during 2004-2008 using gravity and surface elevation observations. Journal of Glaciology 62, 888-904, doi: 10.1017/ jog.2016.76.

Young D.A., Wright A.P., Roberts J.L., Warner R.C., Young N.W., Greenbaum J.S., Schroeder D.M., Holt J.W., Sugden D.E., Blankenship D.D., van Ommen T.D. \& Siegert M.J. 2011. A dynamic early East Antarctic ice sheet suggested by ice-covered fjord landscapes. Nature 474, 72-75, doi: 10.1038/nature 10114 .

Yu J., Liu H., Jezek K.C., Warner R.C. \& Wen J. 2010. Analysis of velocity field, mass balance, and basal melt of the Lambert Glacier-Amery Ice Shelf system by incorporating Radarsat SAR interferometry and ICESat laser altimetry measurements. Journal of Geophysical Research-Solid Earth 115, B 11102 , doi: 10.1029/2010jb007456.

Zhang S., Dongchen E., Wang Z., Li Y., Jin B. \& Zhou C. 2008. Ice velocity from static GPS observations along the transect from Zhongshan Station to Dome A, East Antarctica. Annals of Glaciology 48, 113-118, doi: 10.3189/17275 6408784700716.

Zwally H.J., Giovinetto M.B., Beckley M.A. \& Saba J.L. 2012. Antarctic and Greenland drainage systems. GSFC Cryospheric Sciences Laboratory. Accessed on the internet at http://icesat4.gsfc.nasa.gov/cryo_data/ant_grn_drainage_ systems.php on 22 June 2018. 